\title{
Prognostic Performance of the CALL Score in Hospitalized Patients with COVID-19 Pneumonia
}

\section{COVID-19 Pnömonisi Tanısı ile Yatarak Tedavi Gören Hastalarda CALL Skorun Prognostik Performansı}

\author{
Işıl Kibar Akıllı1, (i) Müge Bilge² \\ ${ }^{1}$ University of Health Sciences Turkey, Bakırköy Dr. Sadi Konuk Training and Research Hospital, Clinic of Chest Disease, Istanbul, Turkey \\ ${ }^{2}$ University of Health Sciences Turkey, Bakırköy Dr. Sadi Konuk Training and Research Hospital, Clinic of Internal Medicine, Istanbul, Turkey
}

\begin{abstract}
Objective: Scoring systems are frequently used to predict disease severity and mortality in many different clinical conditions. The prognostic significance of a new scoring system developed for patients who are hospitalized due to Coronavirus disease-2019 (COVID-19) pneumonia, which is named CALL that stands for comorbidity $(C)$, age $(A)$, lymphocyte count $(L)$, and lactate dehydrogenase $(L D H)(L)$, was evaluated.

Methods: This is a retrospective and observational study on 582 patients who were hospitalized due to moderate or severe COVID-19 pneumonia after being diagnosed as positive using the real-time polymerase chain reaction testing. CALL scores were evaluated in the two groups of patients, namely the survivors and the non-survivors.

Results: Among all patients, 339 (58.24\%) were males and 272 (46.73\%) were older than 60 years. Comorbidities were not found in 174 (29.89 \%) patients, whereas 408 (70.11\%) had one or more comorbidities, mainly hypertension ( $n=275,47.25 \%)$, diabetes mellitus ( $n=192,32.98 \%)$, and coronary artery disease $(n=78,13.4 \%)$. Class A consist of $113(19.41 \%)$ patients $(4-6$ s), $219(37.62 \%)$ in Class B (7-9 s), and $250(42.95 \%)$ in Class C (10-13 s). In-hospital mortality was found to be 6\% (35 cases). Only 1 (0.88\%) patient in Class A and 27 (10.8\%) in Class C were deceased. As a result, in-hospital mortality was observed as 27 patients in Class $C$ and 1 in Class $A$. The receiver operating characteristic analysis was used to assess the performance of the CALL score; the area under the curve was 0.76 ( $95 \%$ confidence interval of $0.68-0.85$ ). Using a cutoff value of 10 points, the sensitivity was $77 \%$ and specificity was $60 \%$ for predicting in-hospital mortality.
\end{abstract}

Conclusion: CALL score was observed to be strongly related to in-hospital mortality. As a simple diagnostic measure, it may be used as a complementary score for the treatment planning and management of COVID-19 pneumonia in pandemic conditions.

Keywords: CALL score, COVID-19 pneumonia, comorbidity, age, lymphocyte, LDH, mortality

\section{öz}

Amaç: Hastalık şiddetinin belirlenmesi ve prognozun öngörülmesinde çeşitli skorlama sistemleri kullanılmaktadır. Mevcut çalışmada, Koronavirüs hastalığı-2019 (COVID-19) pnömonisinde yüksek riskli hastaların saptanması amacı ile geliştirilen, 4 parametreden oluşan ve CALL skor C: komorbidite, A: yaş, L: lenfosit sayısı ve L: laktat dehidrojenaz (LDH) olarak adlandırılan, yeni bir skor sisteminin sonucu öngörebilme yetisinin değerlendirilmesi amaçlanmıştır.

Gereç ve Yöntem: 1 Eylül 2020-31 Aralık 2020 tarihleri arasında yatarak tedavi gören, Ters transkripsiyon polimeraz zincir reaksiyonu testi ile doğrulanmış, orta ve ağır şiddetli COVID-19 pnömonisi olan hastaların tıbbi kayıtlarının retrospektif analizi yapıldı. Çalışmaya toplam 582 hasta dahil edildi. CALL skoru sonuçları sağ kalanlar ve kaybedilenler olmak üzere iki hasta grubu için karşılaştırıldı.

Bulgular: $339(\% 58,24)$ erkek hastanın olduğu çalışmada, $272(\% 46,73)$ hastanın 60 yaş üzerinde olduğu saptandı. 174 $(\% 29,89)$ hastada herhangi bir komorbidite bulunmazken $408(\% 70,11)$ hastada bir veya daha fazla komorbidite olduğu gözlendi. Komorbiditeler arasında ilk üç sırada hipertansiyon $(275, \% 47,25)$, diyabet $(192, \% 32,98)$ ve koroner arter hastalığı $(78, \% 13,4)$ yer almaktaydı. CALL skoru sınıflamasına göre; 113 $(\% 19,41)$ hasta sınıf A $(4-6$ puan), $219(\% 37,62)$ hasta sınıf B $(7-9$ puan) ve $250(\% 42,95)$ hasta sınıf C $(10-13$ puan) olarak kaydedildi. Sınıf A'da sadece $1(\% 0,88)$ hastanın, sınıf C'de ise $27(\% 10,8)$ hastanın kaybedildiği saptandı. Hastane içi mortalite oranı \%6 $(35$ hasta) bulundu. Kaybedilen toplam 35 hasta değerlendirildiğinde; 27 hastanın sınıf C, 7 hastanın sınıf B ve 1 hastanın sınıf A kategorisinde bulunduğu gözlendi. CALL skorun performansını değerlendirmek amacı ile kullanılan Receiver operating characteristics analizinde arena eğri altında 0,76 (\%95 güven aralığı, 0,68-

Address for Correspondence: Işıl Kibar Akıllı, University of Health Sciences Turkey, Bakırköy Dr. Sadi Konuk Training and Research Hospital, Clinic of Chest Disease, Istanbul, Turkey

Phone: +90 5423450413 E-mail: isilkibar@yahoo.com ORCID ID: orcid.org/0000-0000-000-000 
0,85) bulundu. Cutoff değeri 10 puan olarak kabul edildiğinde, CALL skorun hastane içi mortaliteyi öngörmede \%77 duyarlılık ve \%60 özgüllüğe sahip olduğu saptandı.

Sonuç: CALL skorun hastane içi mortalite ile güçlü bir şekilde ilişkili olduğu gözlendi. CALL skoru, özellikle pandemi koşulları dikkate alındığında COVID-19 pnömonisinin tedavi yönetiminde basit, yardımcı ve tamamlayıcı bir skor olarak kullanılabilir.

Anahtar Kelimeler: CALL skor, COVID-19 pnömonisi, komorbidite, yaş, lenfosit, LDH, mortalite

\section{INTRODUCTION}

The novel coronavirus Severe Acute Respiratory syndromecoronavirus-2 (SARS-CoV-2), which was declared as an epidemic by the World Health Organization in March 2020, continues to be a life-threatening problem worldwide. SARS-CoV-2 appears in various clinical forms, such as rapidly progressing hypoxemia and acute respiratory distress syndrome, viral pneumonia, and/or cytokine storm that lead to a consequent hyperinflammatory state and death (1). Coronavirus disease-2019 (COVID-19) progresses with higher mortality among elderly patients with comorbidities, such as diabetes, hypertension, cardiovascular disease, and cerebrovascular disease (2). Early identification of patients who may develop critical illness is of great importance and may support appropriate treatment delivery and resources optimization.

Several known scoring systems are being used in the management of patients with many critical conditions, and the process of patient care, hospitalization, or admission to the intensive care unit (ICU) can be decided based on these scores (3). New scoring systems are still being developed for COVID-19, one of which is the CALL score by Ji et al. (4) that was derived based on patients' comorbidities $(C)$, age $(A)$, lymphocyte count $(L)$, and serum lactate dehydrogenase (LDH) levels $(L)$ at admission. CALL was developed to identify a patient group at high risk of disease progression. Advanced age (>60 years), high level of LDH, and low lymphocyte count $(<1.0 \times 109 / L)$ are independent high-risk factors for the progression of COVID-19, and the CALL score contributes to its prediction (4). Studies have shown that the newly developed predictive model, CALL score for COVID-19, may predict disease progression and in-hospital deaths (4-6).

This retrospective study aimed to develop a metric that would specifically incorporate the information related to comorbidity, thus the CALL score was used to predict COVID-19 hospital mortality. The classification method, which was widely accepted in many former studies in the literature was based on survivors/non-survivors, thus using the same classification system was preferred. However, we further investigated these patients in two groups with a more graded classification system as $A, B$, and $C$.

\section{METHODS}

\section{Study Design and Cohort}

This single-center, cross-sectional retrospective study was conducted at our hospital in Istanbul, Level-3 pandemic, which included 986 patients who are confirmed for COVID-19 from September 1, 2020, to December 31, 2020. Demographic data (age and gender), vital signs as heart rate, respiratory rate, and blood pressure, oxygen saturation $\left(\mathrm{SpO}_{2}\right)$, and mean oxygen requirement at hospitalization duration, comorbidity status, laboratory parameters including complete blood count, c-reactive protein, procalcitonin, cardiac enzymes, coagulation profile, D-dimer, liver and renal functions, LDH, and arterial blood gas results of patients were collected. Nasal and pharyngeal swabs yielding real-time-polymerase chain reaction results, thoracic computerized tomography (CT) results, and clinical outcomes (mortality, discharge, and hospitalization period), as well as comorbidities, were recorded. Patients with incomplete data and pregnant women were excluded from the study. Patients who did not have any clinical or laboratory data or who had pneumonia arising from other causes were excluded from the study. After the exclusion, 582 patients ( $\geq 18$ years) who were hospitalized with the diagnosis of moderate or severe COVID-19 pneumonia were included in the study. None was admitted to the ICU. The data was categorized as moderate or severe based on severity classification regarding the "Chinese Guidelines for Diagnosis and Treatment of Novel Coronavirus Pneumonia" (Trial Version 7) (7). Patients with moderate COVID-19 had a fever $\left(>37.3^{\circ} \mathrm{C}\right)$ and respiratory symptoms identified by radiological findings that suggest pneumonia. The existence of any one of the following criteria was assumed to be a sufficient condition to consider the patient as severe: (1) respiratory distress ( $\geq 30$ breaths/min), (2) oxygen saturation of $\leq 93 \%$ at rest, and (3) arterial partial pressure of oxygen /fraction of inspired oxygen of $\leq 300 \mathrm{mmHg}$ (1 $\mathrm{mmHg}: 0.133 \mathrm{kPa}$ ). CT scans were obtained from all patients during hospital admission. CT results were classified as mild, moderate, and severe involvement by an expert radiologist (8). Comorbidity was defined as the presence of at least one of the following: hypertension, diabetes, cardiovascular disease, chronic lung disease (Asthma and chronic obstructive pulmonary disease), chronic liver disease, human 
immunodeficiency virus infection, or at least 6 months of active malignancy (4). CALL score was calculated for each patient from the retrospectively obtained data as follows: no comorbidity $=1$ point; comorbidity $=4$; age of $\leq 60=1$ and $>60=3$; lymphocyte of $>1.0 \times 10^{\%} / \mathrm{L}=1$ and $\leq 1.0 \times 10^{9} / \mathrm{L}=3$; and $\mathrm{LDH}$ of $\leq 250 \mathrm{U} / \mathrm{L}=1,250-500 \mathrm{U} / \mathrm{L}=2$, and $>500 \mathrm{U} / \mathrm{L}=3$ points. CALL score was classified as class A with 4-6 points, wherein patients show $<10 \%$ probability of progression and were considered as low risk; class B with 7-9 points, wherein patients have $10 \%-40 \%$ probability of progression and at intermediate risk; and class C with 10-13 points, wherein patients have $>50 \%$ probability of progression and at high risk (4).

The primary endpoint was defined as the in-hospital death. All cases that are enrolled in the study were managed according to the "COVID 19 treatment protocol of the Turkish Health Ministry" (9). The research was first registered in the data of the "Turkish Health Ministry Scientific Research Committee" and then reviewed and approved by the Local Ethics Committee University of Health Sciences Turkey, Bakırköy Dr. Sadi Konuk Training and Research Hospital (no: 2021-05-10, date: 01.03.2021).

\section{Statistical Analysis}

All statistical analyses were performed in commercially available Statistical Package for the Social Sciences software version 21 (Statistical Package for the Social Sciences Inc., Chicago, IL, USA). Patient characteristics were summarized using descriptive statistics. Continuous variables were compared using either the unpaired t-test to compare two variables or a one-way analysis of variance to compare multiple variables. Categorical variables were compared using the Chi-square test. The Mann-Whitney $U$ test was used to evaluate continuous variables with the non-normal distribution. A p-value of $<0.05$ was accepted as statistically significant. Receiver operating characteristic (ROC) analysis was carried out to identify an index for the prediction of inhospital death.

\section{RESULTS}

Baseline data characterizing the patients and their comorbidities are given in Table 1. Laboratory measurements, CT results, and disease severity are presented in Table 2. CALL score components and classifications are shown in Tables 3 and 4, respectively. Among 582 patients, 408 (70.11\%) had comorbidities that mainly include hypertension ( $n=275,47.25 \%)$, diabetes mellitus ( $n=192,32.98 \%)$, and coronary artery disease $(n=78$, 13.4\%). Based on established categories, 251 (43.12\%) patients were classified as moderate and 331 (56.88\%) as severe. Pulmonary involvement in the thorax CT was mild in $125(21.47 \%)$, moderate in $258(44.32 \%)$, and severe in 199 (34.21\%) patients. Class A consists 113 (19.41\%) patients (4-6 points), 219 (37.62\%) in class B (7-9 points), and 250 (42.95\%) in class C (10-13) (Table 4). In addition, 181 patients (54.69 $\%$ ) with severe disease were found in class $C$ and 39 (11.78\%) in class $A$.

The clinical characteristics of survivor and non-survivor groups were compared. No statistically significant difference was found between genders; however, 25 (71.42 $\%)$ patients who died were male. Comorbidity, age, LDH, and lymphocyte as components of the CALL score were significantly different between the two groups based on univariate analyses.

In addition to comorbidity numbers, respiratory rate, oxygen saturation, supplemental oxygen requirement, heart rate, urea, albumin, troponin-I, disease severity, and thorax CT score were found to be significantly different between the two groups. Duration of hospitalization was $11.26 \pm 5.89$ days in survivors, whereas $11.8 \pm 7.29$ days in non-survivors and was insignificant. In-hospital mortality was found to be $6 \%$ (35 cases), wherein 34 (97.15\%) cases were severe.

The median age was $71.57 \pm 13.56$ years in non-survivors, whereas $59.39 \pm 14.51$ years in survivors $(p<0.001)$. Among all patient, 26 (74.28\%) were deceased and were older than 60 years $(p=0.001), 30(85.72 \%)$ had at least one comorbidity, and 22 (62.87\%) had two or more comorbidities. As expected, members of the non-survivor group were older and had more comorbidities $(p<0.001$ and $p=0.04$, respectively). Comorbid hypertension, congestive heart failure, cerebrovascular disease, and malignancy were significantly more common in non-survivors than those in survivors ( $p=0.01, p=0.01, p=0.002$, and $p=0.005$, respectively). $\ln 25$ (71.43\%) of the deceased patients, the lymphocyte count was found to be $1.0 \times 10^{\%} / \mathrm{L}$ or less and in $10(28.57 \%)$ and was $>1.0 \times 10^{9} / \mathrm{L}$ in 15 patients $(p<0.001)$. In the non-survivor group, LDH was $<250 \mathrm{U} / \mathrm{L}$ in 6 (17.14\%), $250-500 \mathrm{U} / \mathrm{L}$ in 20 (57.14\%), and $>500 \mathrm{U} / \mathrm{L}$ in 9 patients $(25.72 \%)(p=0.01)$.

In the deceased group, 34 (97.15\%) were severe, whereas only 1 patient (2.85\%) was moderate. In this group, according to the thorax CT findings, moderate involvement was found in 11 (31.42\%) and severe involvement was found in $23(65.73 \%)$ cases. Therefore, deceased patients had significantly higher disease severity status and thorax CT scores compared to survivors $(p<0,001)$. Of 582 patients, $113(19.41 \%)$ were in class $A, 219(37.62 \%)$ in class $B$, and 250 (42.95\%) in class C. Class C had 27 (10.8\%) deceased patients, whereas $1(0.88 \%)$ in class A. Out of 250 patients, 181 (72.4\%) in class $C$ were severe. 
Table 1. Evaluation of baseline characteristics and comorbidities for survivors and nonsurvivors

\begin{tabular}{|c|c|c|c|}
\hline & Survivors $(n=547)$ & Non-survivors $(n=35)$ & $p$ \\
\hline Age, years & $59.39 \pm 14.51$ & $71.57 \pm 13.56$ & $<0.001$ \\
\hline Sex male, 339 (58.24\%) & $314(57.4 \%)$ & $25(71.42 \%)$ & NS \\
\hline Body temperature, ${ }^{\circ} \mathrm{C}$ & $36.87 \pm 0.63$ & $36.93 \pm 0.7$ & NS \\
\hline Systolic blood pressure, $\mathrm{mmHg}$ & $127.18 \pm 18.86$ & $133.14 \pm 19.13$ & NS \\
\hline Diastolic blood pressure, $\mathrm{mmHg}$ & $71.54 \pm 10.60$ & $72.31 \pm 10.58$ & NS \\
\hline Heart rate, per minute & $84.23 \pm 16.18$ & $90.05 \pm 20.15$ & 0.04 \\
\hline Respiratory rate, per min & $20.70 \pm 4.34$ & $29.91 \pm 4.59$ & $<0.001$ \\
\hline $\mathrm{SpO}_{2}$ (median; under oxygen support) & $94.51 \pm 1.98$ & $92.62 \pm 2.45$ & $<0.001$ \\
\hline $\mathrm{O}_{2}$ support, L/per min & $3.66 \pm 5.47$ & $13.45 \pm 8.35$ & $<0.001$ \\
\hline \multicolumn{4}{|l|}{ Comorbidities, n (\%) } \\
\hline Arterial hypertension 275 (47.25) & $251(45.88)$ & $24(68.57)$ & 0.01 \\
\hline Diabetes mellitus 192 (32.98) & $179(32.72)$ & $13(37.14)$ & NS \\
\hline Coronary artery disease 78 (13.4) & $71(12.97)$ & $7(20)$ & NS \\
\hline Congestive heart failure 27 (4.63) & $22(4.02)$ & $5(14.28)$ & 0.01 \\
\hline Cerebrovascular disease 17 (2.92) & $12(2.19)$ & $5(14.28)$ & 0.002 \\
\hline Asthma 49 (8.41) & $46(8.40)$ & $3(8.57)$ & NS \\
\hline COPD" 17 (2.92) & $16(2.92)$ & $1(2.85)$ & NS \\
\hline Malignancy 29 (4.98) & $23(4.20)$ & $6(17.14)$ & 0.005 \\
\hline Chronic kidney disease 28 (4.81) & $26(4.75)$ & $2(5.71)$ & NS \\
\hline
\end{tabular}

"COPD: Chronic obstructive pulmonary disease

Univariate analysis showed that age older than 60 years [odds ratio (OR): 3.53 , 95\% confidence interval $(\mathrm{Cl})$ : 1.627.68] and lymphocyte count of $\leq 1.0 \times 10^{9} / \mathrm{L}$ (OR: $5.90,95 \%$ $\mathrm{Cl}$ : 2.53-13.74) were associated with mortality. ROC analysis was used to assess the performance of the CALL model; the area under the curve (AUC) was $0.76(95 \% \mathrm{Cl}$ : 0.68$0.85, p<0.001$ ) (Figure1). Using a cutoff value of 10 points, sensitivity was $77 \%$ and specificity was $60 \%$ in predicting inhospital mortality.

Therefore, mortality was associated with advanced age (>60 years), presence of certain comorbidities (hypertension, congestive heart failure, cerebrovascular disease, and malignities), higher LDH, lower lymphocyte, and higher CALL scores. In addition, mortality was found to be associated with lower oxygen saturation, tachypnea, need for supplemental oxygen support, high urea, troponin-I, low albumin levels, disease severity status, and thorax CT score.

\section{DISCUSSION}

Considering the high infectivity and mortality rates of COVID-19 with pneumonia, early disease diagnosis is essentially critical. Blood tests and simple scoring systems

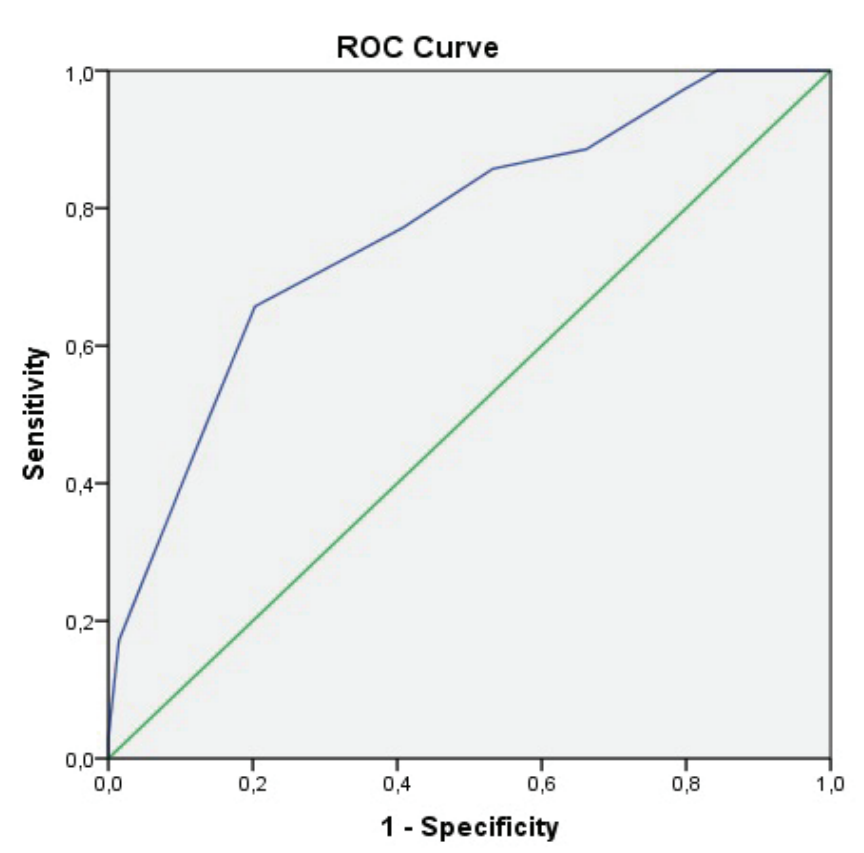

Figure 1. ROC curve for CALL score in predicting mortality. AUC 0.76 (95\% Cl: 0.68-0.85).

ROC: Receiver operating characteristic, AUC: Area under curve, $\mathrm{Cl}$ : Confidence interval 
play an important role in the early diagnosis, considering the information they provide to physicians regarding the inflammatory process.

Previous studies reported that advanced age, lymphopenia, and high-level LDH were correlated with worse outcomes and mortality (10-18). Contrarily, the presence of comorbidity as an independent risk factor is still controversial. However, several studies claimed that the presence of comorbidities was an independent risk factor $(10,12,19-22)$. CALL score was first defined by Ji et al. (4) who excluded severe patients in their cohort. Contrarily, Kamran et al. (6) included severe and critical cases in their study and concluded that CALL score was a reliable indicator to predict the progression and mortality of disease although the presence of unaccompanied comorbidities was not an independent risk factor. Additionally, some studies have reported that comorbidity was not predictive for disease severity $(6,23$ 26). Guan et al. (12) did not only report that patients with any comorbidity had worse clinical outcomes but also reported that the number of comorbidities was an important risk factor for composite outcomes (ICU admission, invasive ventilation, or death) (19).

Ucan et al. (27) determined that community-acquired pneumonia scores were more predictive of mortality and

Table 2. Evaluation of laboratory results, CT results, and disease severity for survivors and nonsurvivors

\begin{tabular}{|c|c|c|c|}
\hline & Survivors $(n=547)$ & Non-survivors $(n=35,6 \%)$ & $p$ \\
\hline Hematocrit, \% & $37.76 \pm 4.76$ & $37.42 \pm 5.425$ & NS \\
\hline Platelet, cells/mL & $247.75 \pm 116.06$ & $213.65 \pm 111.26$ & NS \\
\hline Neutrophil, cells/mL & $5.37 \pm 4.38$ & $6.31 \pm 3.97$ & NS \\
\hline Lymphocytes, cells/mL & $1.22 \pm 0.57$ & $0.84 \pm 0.58$ & $<0.001$ \\
\hline Glucose, mg/dL & $148.88 \pm 68.33$ & $164.04 \pm 79.26$ & NS \\
\hline Urea, mg/dL & $38.99 \pm 26.96$ & $58.59 \pm 34.27$ & $<0.001$ \\
\hline Creatinine, mg/dL & $0.96 \pm 0.74$ & $1.00 \pm 0.41$ & NS \\
\hline$A L T, U / L$ & $44.02 \pm 33.14$ & $44.60 \pm 21.76$ & NS \\
\hline AST, U/L & $41.32 \pm 35.99$ & $40.20 \pm 32.08$ & NS \\
\hline Lactate dehydrogenase, U/L & $336.63 \pm 139.10$ & $421.60 \pm 221.96$ & 0.001 \\
\hline C-reactive protein, $\mathrm{mg} / \mathrm{L}$ & $101.31 \pm 77.21$ & $123.07 \pm 66.76$ & NS \\
\hline Procalcitonin, $\mathrm{ng} / \mathrm{mL}$ & $0.41 \pm 0.50$ & $1.01 \pm 1.64$ & NS \\
\hline Ferritin, mcg/L & $461.69 \pm 564.75$ & $628.96 \pm 598.92$ & NS \\
\hline D-dimer, mcg FEU/mL & $0.70 \pm 1.02$ & $1.01 \pm 1.01$ & NS \\
\hline Fibrinogen, mg/dL & $490.10 \pm 119.89$ & $516.02 \pm 137.01$ & NS \\
\hline INR & $1.05 \pm 0.16$ & $1.08 \pm 0.21$ & NS \\
\hline Troponin-I, ng/mL & $12.20 \pm 25.73$ & $32.09 \pm 64.21$ & $<0.001$ \\
\hline Albumine, g/dL & $36.54 \pm 5.86$ & $32.70 \pm 5.68$ & $<0.001$ \\
\hline $\mathrm{CT}, \mathrm{n}(\%)$ & - & - & $<0.001$ \\
\hline Mild 125 (21.47) & $124(22.66)$ & $1(2.85)$ & - \\
\hline Moderate 258 (44.32) & $247(45.15)$ & $11(31.42)$ & - \\
\hline Severe 199 (34.21) & $176(32.19)$ & $23(65.73)$ & - \\
\hline Disease severity status, n (\%) & - & - & $<0.001$ \\
\hline Moderate, 251(43.12) & $250(45.7)$ & $1(2.85)$ & - \\
\hline Severe, 331 (56.88) & $297(54.3)$ & $34(97.15)$ & - \\
\hline Hospitalization, days & $11.26 \pm 5.89$ & $11.80 \pm 7.29$ & NS \\
\hline Death, n (\%) & - & $35(6 \%)$ & - \\
\hline
\end{tabular}


progression in COVID-19 than specific COVID-19 scoring systems, hence they suggested that the CALL score could be used to decide for outpatient management in COVID-19. Their study reported no deaths in CALL score class A (27). However, our study reported 1 (0.88\%) patient who died in class A and 27 (10.8\%) in class C. Ji et al. (4) also found in their study that $>96 \%$ of participants did not progress to serious disease with CALL scores of 4-6 points (Class A).

Several studies showed that the CALL score was a powerful prognosticator to predict the progression to severe COVID-19, identify critically ill patients who require an ICU admission, in-hospital mortality, worsening illness, and associated fatality $(5,6,26,28)$. Our study also demonstrated the high performance of the CALL model in predicting the disease severity and hospital mortality; the AUC was 0.76 (95\% Cl: $0.68-0.85)$ and using a cutoff value of 10 points,

Table 3. Components of CALL score

\begin{tabular}{|c|c|c|c|}
\hline & $\begin{array}{l}\text { Survivors } \\
(n=547)\end{array}$ & $\begin{array}{l}\text { Non-survivors } \\
(n=35,6 \%)\end{array}$ & $p$ \\
\hline $\begin{array}{l}\text { Comorbidity } \\
\text { numbers, n (\%) }\end{array}$ & - & - & 0.04 \\
\hline Without, 174 (29.89) & $169(30.89)$ & $5(14.28)$ & - \\
\hline With, 408 (70.11) & $378(69.11)$ & $30(85.72)$ & - \\
\hline With 1, 151 (25.94) & $143(26.14)$ & $8(22.85)$ & - \\
\hline With $\geq 2,257$ (44.17) & $235(42.97)$ & $22(62.87)$ & - \\
\hline \multicolumn{4}{|l|}{ Lymphocyte, n (\%) } \\
\hline >1×109/L, 331 (56.87) & $321(58.68)$ & $10(28.57)$ & - \\
\hline$\leq 1 \times 10^{9} / \mathrm{L}, 251(43.13)$ & $226(41.32)$ & $25(71.43)$ & $<0.001$ \\
\hline \multicolumn{4}{|l|}{ Age, n (\%) } \\
\hline$>60$ years, $272(46.73)$ & $246(44.97)$ & $26(74.28)$ & 0.001 \\
\hline$\leq 60$ years, $310(53.27)$ & $301(55.03)$ & $9(25.72)$ & - \\
\hline \multicolumn{4}{|l|}{ LDH, n (\%) } \\
\hline$<250$ U/L, 150 (25.77) & $144(26.32)$ & $6(17.14)$ & - \\
\hline 250-500 U/L, 365 (62.71) & $345(63.07)$ & $20(57.14)$ & - \\
\hline$>500$ U/L, 67 (11.51) & $58(10.61)$ & $9(25.72)$ & 0.01 \\
\hline LDH: Lactate dehydrogenase & & & \\
\hline
\end{tabular}

sensitivity was $77 \%$ and specificity was $60 \%$ in predicting in-hospital mortality.

Moreover, another study showed that the CALL score performed well for 30-day mortality but not for 7-day ICU admission (29). Contrarily, Al Hassan et al. (25) showed that the CALL score had a poor discriminatory value for the composite outcome of ICU admission or death. Similarly, Shi et al. (30) stated that the CALL score performed poorly in predicting mortality and critical illness.

Recently, Cabanillas et al. (31) suggested that the CALL score was useful in managing the treatment of patients with COVID-19 and were able to prevent the development of respiratory failure by giving methylprednisolone treatment to high-risk patients, whom they identified with the CALL score (31). In addition, the "CALL-(interleukin)IL-6 score," which was created by adding IL-6 to the CALL score, showed a significantly better prediction of in-hospital mortality and progression to severity than the original CALL score (32).

Our study found older age, presence, and multiplicity of comorbidity, lymphopenia, and increased LDH levels to be strongly associated with mortality. In addition, increased respiratory rate, lower oxygen saturation, severe disease status, and higher thorax CT scores were found to be associated with death. CALL score proved to be a reliable prognosticator for mortality. Older age and the presence of comorbidity were thought to be associated with mortality.

\section{CONCLUSION}

CALL score achieved a significant predictor of mortality in COVID-19. Especially considering the pandemic conditions, the CALL model, which consists of only four clinical parameters, helps the clinician in predicting mortality and providing appropriate treatment with its high accuracy and easy-to-use features. The ambiguity of results in several studies on CALL scores may vary due to sample sizes or demographic differences. Nevertheless, prospective multicentered studies in extensive demographic samples are needed to confirm the CALL score and reveal the role of comorbidities.

Table 4. CALL score classification

\begin{tabular}{lllll}
\hline & Mortality & & Disease Severity & \multicolumn{1}{c}{$\mathrm{p}$} \\
\hline CALL Score (Points) & $\begin{array}{l}\text { Non-survivors } \\
\mathrm{n}=35(6 \%)\end{array}$ & $\begin{array}{l}\text { Survivors } \\
\mathrm{n}=547(94 \%)\end{array}$ & $\begin{array}{l}\text { Moderate } \\
\mathrm{n}=251(43.12 \%)\end{array}$ & $\begin{array}{l}\text { Severe } \\
\mathrm{n}=331(56.87 \%)\end{array}$ \\
\hline Class A (4-6 s) $\mathrm{n}=113(19.41 \%)$ & $1(0.88)$ & $112(99.11)$ & $74(65.48)$ & $39(34.51)$ \\
\hline Class B (7-9 s) $\mathrm{n}=219(37.62 \%)$ & $7(3.19)$ & $212(96.80)$ & $108(49.31)$ & $111(50.68)$ \\
\hline Class C (10-13 s) $\mathrm{n}=250(42.95 \%)$ & $27(10.8)$ & $223(89.2)$ & $69(27.6)$ & $181(72.4)$ \\
\hline
\end{tabular}




\section{ETHICS}

Ethics Committee Approval: The research was first registered in the data of the "Turkish Health Ministry Scientific Research Committee" and then reviewed and approved by the Local Ethics Committee University of Health Sciences Turkey, Bakırköy Dr. Sadi Konuk Training and Research Hospital (no: 2021-05-10, date: 01.03.2021).

Informed Consent: This retrospective study.

\section{Authorship Contributions}

Surgical and Medical Practices: I.K.A., M.B., Concept: I.K.A., M.B., Design: I.K.A., M.B., Data Collection or Processing: I.K.A., M.B., Analysis or Interpretation: I.K.A., M.B., Literature Search: I.K.A., M.B., Writing: I.K.A., M.B.

Conflict of Interest: No conflict of interest was declared by the authors.

Financial Disclosure: The authors declared that this study received no financial support.

\section{REFERENCES}

1. World Health Organization timeline-COVID-19. Available at: https:// www.who.int/emergencies/diseases/novel-coronavirus-2019/ interactive-timeline\#tevent-71. Accessed 31 June 2021.

2. Liu K, Chen Y, Lin R, Han K. Clinical features of COVID-19 in elderly patients: A comparison with young and middle-aged patients. J Infect 2020;80:e14-8.

3. Wynants L, Van Calster B, Collins GS, Riley RD, Heinze G, Schuit E, et al. Prediction models for diagnosis and prognosis of covid-19: systematic review and critical appraisal. BMJ 2020;369:m1328.

4. Ji D, Zhang D, Xu J, Chen Z, Yang T, Zhao P, et al. Prediction for Progression Risk in Patients With COVID-19 Pneumonia: The CALL Score. Clin Infect Dis 2020;71:1393-9.

5. Grifoni E, Valoriani A, Cei F, Vannucchi V, Moroni F, Pelagatti L, et al. The CALL Score for Predicting Outcomes in Patients With COVID-19. Clin Infect Dis 2021;72:182-3.

6. Kamran SM, Mirza Z-H, Moeed HA, Naseem A, Hussain M, Fazal I, et al. CALL Score and RAS Score as Predictive Models for Coronavirus Disease 2019. Cureus [Internet]. 2020 Nov 7 [cited 2021 Aug 25]; Available from: https://www.cureus.com/articles/43938-call-scoreand-ras-score-as-predictive-models-for-coronavirus-disease-2019.

7. Diagnosis and Treatment Protocol for Novel Coronavirus Pneumonia (Trial Version 7). Chin Med J (Engl) 2020;133:1087-95.

8. Yang R, Li X, Liu H, Zhen Y, Zhang $X$, Xiong $Q$, et al. Chest CT Severity Score: An Imaging Tool for Assessing Severe COVID-19. Radiol Cardiothorac Imaging 2020;2:e200047.

9. Republic of Turkey Ministry of Health. Covid-19 (SARS-CoV-2 Infection) Guide. Available @:covid-19rehberieriskinhastatedavisip df.pdf (saglik.gov.tr), (Accessed 20/07/2020.).

10. Stawicki SP, Jeanmonod R, Miller AC, Paladino L, Gaieski DF, Yaffee AQ, et al. The 2019-2020 Novel Coronavirus (Severe Acute Respiratory Syndrome Coronavirus 2) Pandemic: A Joint American College of Academic International Medicine-World Academic Council of Emergency Medicine Multidisciplinary COVID-19 Working Group Consensus Paper. J Glob Infect Dis 2020;12:47-93.

11. Fathi N, Rezaei N. Lymphopenia in COVID-19: Therapeutic opportunities. Cell Biol Int 2020;44:1792-7.
12. Guan WJ, Ni ZY, Hu Y, Liang WH, Ou CQ, He JX, et al. Clinical Characteristics of Coronavirus Disease 2019 in China. N Engl J Med 2020;382:1708-20.

13. Wang $F$, Nie J, Wang $H$, Zhao $Q$, Xiong $Y$, Deng $L$, et al. Characteristics of Peripheral Lymphocyte Subset Alteration in COVID-19 Pneumonia. J Infect Dis 2020;221:1762-9.

14. Henry BM, Aggarwal G, Wong J, Benoit S, Vikse J, Plebani M, et al. Lactate dehydrogenase levels predict coronavirus disease 2019 (COVID-19) severity and mortality: A pooled analysis. Am J Emerg Med 2020;38:1722-6.

15. Shi J, Li Y, Zhou X, Zhang Q, YeX, Wu Z, et al. Lactate dehydrogenase and susceptibility to deterioration of mild COVID-19 patients: a multicenter nested case-control study. BMC Med $2020 ; 18: 168$.

16. Liang W, Liang H, Ou L, Chen B, Chen A, Li C, et al. Development and Validation of a Clinical Risk Score to Predict the Occurrence of Critical Illness in Hospitalized Patients With COVID-19. JAMA Intern Med 2020;180:1081-9.

17. Wang D, Hu B, Hu C, Zhu F, Liu X, Zhang J, et al. Clinical Characteristics. of 138 Hospitalized Patients With 2019 Novel Coronavirus-Infected Pneumonia in Wuhan, China. JAMA 2020;323:1061-9.

18. Chen N, Zhou M, Dong X, Qu J, Gong F, Han Y, et al. Epidemiological and clinical characteristics of 99 cases of 2019 novel coronavirus pneumonia in Wuhan, China: a descriptive study. Lancet 2020;395:507-13.

19. Guan WJ, Liang WH, Zhao Y, Liang HR, Chen ZS, Li YM, et al. Comorbidity and its impact on 1590 patients with COVID-19 in China: a nationwide analysis. Eur Respir J 2020;55:2000547.

20. Yang $X, Y u Y, X u$ J, Shu H, Xia J, Liu H, et al. Clinical course and outcomes of critically ill patients with SARS-CoV-2 pneumonia in Wuhan, China: a single-centered, retrospective, observational study. Lancet Respir Med 2020;8:475-81.

21. Wendel Garcia PD, Fumeaux T, Guerci P, Heuberger DM, Montomoli J, Roche-Campo F, et al. Prognostic factors associated with mortality risk and disease progression in 639 critically ill patients with COVID-19 in Europe: Initial report of the international RISC-19-ICU prospective observational cohort. EClinicalMedicine 2020;25:100449.

22. Docherty $A B$, Harrison EM, Green $C A$, Hardwick HE, Pius R, Norman L, et al. Features of 20133 UK patients in hospital with covid-19 using the ISARIC WHO Clinical Characterisation Protocol: prospective observational cohort study. BMJ 2020;369:m1985.

23. Zhou F, Yu T, Du R, Fan G, Liu Y, Liu Z, et al. Clinical course and risk factors for mortality of adult inpatients with COVID-19 in Wuhan, China: a retrospective cohort study. Lancet 2020;395:1054-62.

24. Zhang C, Qin L, Li K, Wang Q, Zhao Y, Xu B, et al. A Novel Scoring System for Prediction of Disease Severity in COVID-19. Front Cell Infect Microbiol $2020 ; 10: 318$.

25. Al Hassan H, Cocks E, Jesani L, Lewis S, Szakmany T. Clinical Risk Prediction Scores in Coronavirus Disease 2019: Beware of Low Validity and Clinical Utility. Crit Care Explor 2020;2:e0253.

26. Olivares F, Muñoz D, Fica A, Delama I, Alvarez I, Navarrete M, et al. Clinical features of 47 patients infected with COVID-19 admitted to a Regional Reference Center. Rev Med Chil 2020;148:1577-88.

27. Ucan ES, Ozgen Alpaydin A, Ozuygur SS, Ercan S, Unal B, Sayiner AA, et al. Pneumonia severity indices predict prognosis in coronavirus disease-2019. Respir Med Res 2021;79:100826.

28. Xu W, Huang C, Fei L, Li W, Xie X, Li Q, et al. A Novel Prediction Model of COVID-19 Progression: A Retrospective Cohort Study. Infect Dis Ther 2021;10:1491-504.

29. Lazar Neto F, Marino LO, Torres A, Cilloniz C, Meirelles Marchini JF, Garcia de Alencar JC, et al. Community-acquired pneumonia 
severity assessment tools in patients hospitalized with COVID-19 a validation and clinical applicability study. Clin Microbiol Infect 2021;27:1037.e1-1037.e8.

30. Shi Y, Pandita A, Hardesty A, McCarthy M, Aridi J, Weiss ZF, et al. Validation of pneumonia prognostic scores in a statewide cohort of hospitalised patients with COVID-19. Int J Clin Pract 202;75. Available from: https://onlinelibrary.wiley.com/doi/10.1111/ ijcp.13926.

31. Cabanillas F, Morales JG, Conde J, Bertrán-Pasarell J, Fernández $R$, Hernandez-Silva $Y$, et al. Single-Arm, Open-Label Phase 2
Trial of Preemptive Methylprednisolone to Avert Progression to Respiratory Failure in High-Risk Patients with COVID-19 [Internet]. Infectious Diseases (except HIV/AIDS); 2021 Mar [cited 2021 Aug 25]. Available from: http://medrxiv.org/lookup/doi/10.1101/2021.0 3.08.21253117.

32. Grifoni E, Vannucchi V, Valoriani A, Cei F, Lamanna R, Gelli AMG, et al. Interleukin-6 added to CALL score better predicts the prognosis of COVID-19 patients. Intern Med J 2021;51:146-7. 